The BDJ News section accepts items that include general news, latest research and diary events that interest our readers. Press releases or articles may be edited, and should include a colour photograph if possible. Please direct your correspondence to the News Editor, Arveen Bajaj at the BDJ, 64 Wimpole Street WIG 8YS or by email to bdj@bda.org

\section{MBE for London dentist}

Hampstead based dentist, Dr Rashmi Patel received an MBE in the Queen's Birthday Honours in June this year, in recognition of her achievements in the field of dentistry. In nearly thirty years of work in the field, as well as working in her own practice Dr Patel is an appointed dentist to the Royal School of Hampstead and at Howard House Home for Children in Hampstead.

She is an examiner for the national dental nurses qualification, a core mentor for the Central London Study Group for Dentists and an examiner for the Royal College of Surgeons. Dr Patel was also one of the early founders of the AngloAsian Odontological Group as well as its President during the establishment of the National Centre for Transcultural Health at the Eastman. She is also a serving member of the Standing Dental Advisory Committee.

She spends much of her spare time fundraising for charities and is currently involved with the Drug and Alcohol Action Programme (www.daap.org.uk).



Dr Patel with the MBE award

\title{
Top marks
}

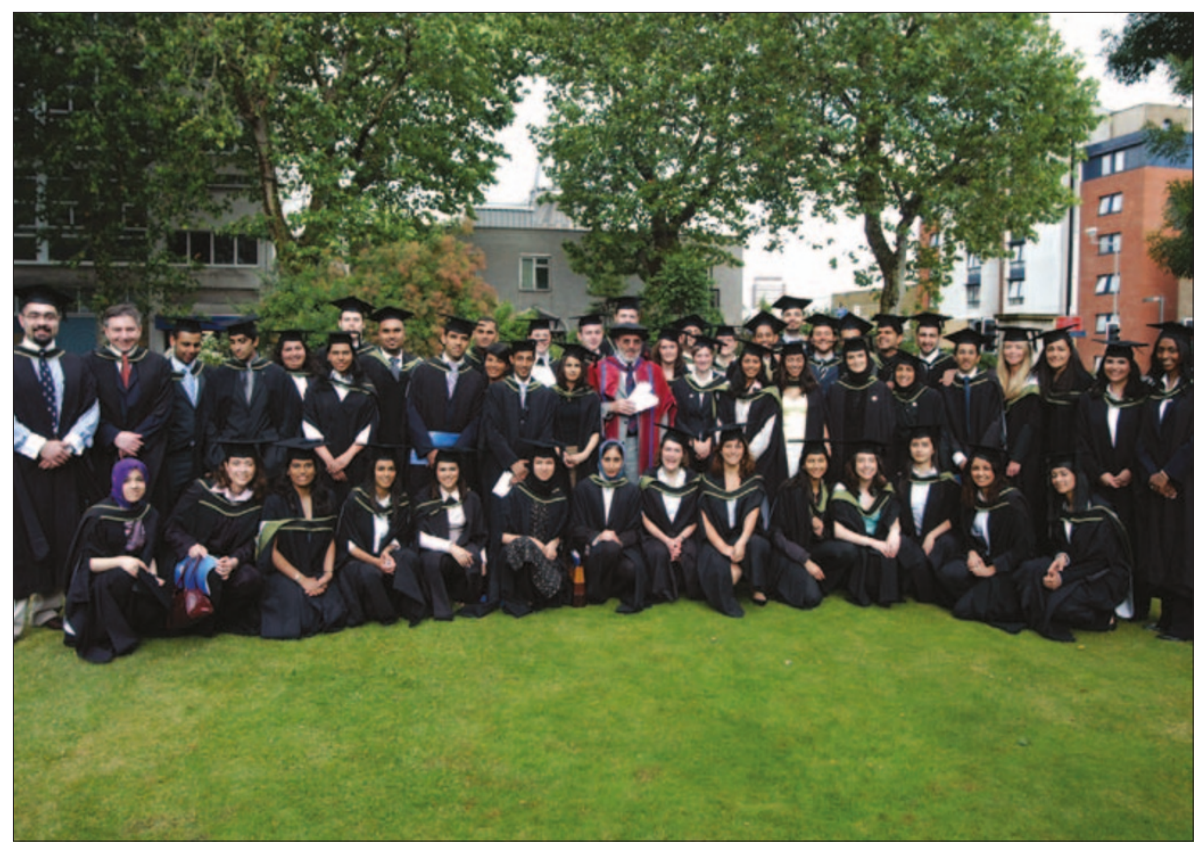

Students from Barts and The London, Queen Mary's School of Medicine and Dentistry, received a rare $100 \%$ pass rate in their final BDS this year, the first time in almost 40 years according to Professor Paul Wright, Director of the Institute of Dentistry. The students presented Professor Wright with a pair of white gloves at the graduation dinner, to celebrate the absence of any failures. The students were the first to have passed through the new integrated BDS curriculum.

\section{Legislation to give more powers to GDC}

The GDC has welcomed the Department of Health's consultation on proposed changes to the Dentists Act (1984).

The changes mean that the Council will have new powers to extend statutory GDC registration to cover the whole dental team, including dental nurses and dental technicians, set up a complaints scheme for non-NHS dental patients and reform its procedures for dealing with misconduct and ill health amongst dental professionals.

It will also introduce new procedures to tackle problems of poor performance in dentists and remove the current restriction on the number of dental bodies corporate.

The DoH is now consulting on proposed changes and the legislation, which is in the form of an Order made under section 60 of the Health Act 1999. It is due to be laid before Parliament later this year.

Section 60 Orders give the Government the power to change regulations, Orders or Acts of Parliament without the need for a Bill to go through the parliamentary procedure leading up to a new Act of Parliament.

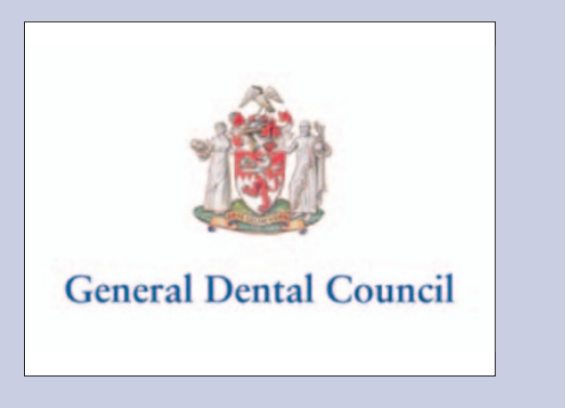




\section{DIARY}

September 2004

Association For Dental Education in Europe 30th Annual Meeting

Date: 1-4.09.04

Venue: Cardiff, Wales, UK

Contact: www.adee2004.uwcm.ac.uk

Email: adee2004@cardiff.ac.uk

IFEA Sixth Endodontic World Congress

Date: 8-11.09.04

Venue: Brisbane Convention and

Exhibition Centre, Queensland, Australia

Tel: (0)7 38585599

Email: ifea2004@im.com.au

www.ifea2004.im.com.au

92nd FDI World Dental Congress

Date: 10-13.09.04

Venue: Delhi, India

Tel: +911123315834

Email: shastri@tci.co.in

www.fdiworldental.org

Cleft care and the patient in the UK, Europe and Beyond

Date: 14.09.04

Venue: Royal Society of Medicine

Contact: Cleft Lip and Palate Association

Tel: +44 (0)207 8334883

Email:info@clapa.com

www.clapa.com

British Orthodontic Conference

Date: 19-22.09.04

Venue: Harrogate

Contact: Ann Wright

Tel: +44 (0)207 8372193

Email:ann.wright@bos.org.uk

\section{Double success}



The Crescent Specialist Dental Centre, Plymouth, recently celebrated a double success in winning two categories in the Wales and West Country regional programme of The National Business Awards. Principal Dr Jeremy Peak collected the award for Entrepreneur of the Year and the Award for Outstanding People Development, given to a business the judges said had made its entire staff feel part of it. The awards are open to companies of all sizes and from any sector and the winners now go through to the judging process for the national awards programme.

\section{Fellowship awarded}

Professor John Greenspan was recently awarded Fellowship of King's College London at the College's Degree Ceremony at the Royal Festival Hall. He is a Professor of Oral Biology and Oral Pathology and the Leland A. and Gladys K. Barber Professor and Dean for Research of the School of Dentistry, University of California at San Francisco (UCSF).

Professor Greenspan's research interests include the oral aspects of AIDS and the role of viruses in oral epithelial and salivary gland lesions. The award of the Fellowship is governed by a statute of the college and reflects distinguished service to the college by member of staff and those associated with it.

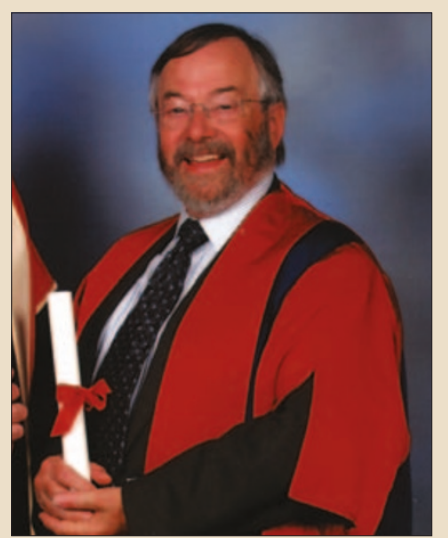

Professor John Greenspan 